\title{
THE EXISTENCE OF HUMAN RIGHTS COURT AS A NATIONAL EFFORT TO ELIMINATE THE SEVERE VIOLATION OF HUMAN RIGHTS IN INDONESIA
}

\author{
Junaedi* $^{*}$ \\ * Ph.D Candidate, School of Law, University of Canberra, Australia.

\section{Article Info} \\ Received : 24 July 2014 | Received in revised form : 12 September 2014 | Accepted : 25 September 2014 \\ Corresponding author's e-mail : junaedi.si@gmail.com
}

\begin{abstract}
The law on human rights court has brought the new hopes for certain people have suffered because of the human rights violation happened in the past government (before the law enacted in the years of 2000). The demand for justice does not only focus on human rights violations, which occurred in the past but also similar human rights violations that will occur in the future. The existence of a permanent Human Rights Court seems to imply that human rights will be upheld and protected. The resolution of past human rights violations through extra-judicial organizations is an advanced step towards resolving the case, whereas a conflict approach can be used to settle the case. The existence of the Human Rights Law provides a new frontier in implementing the principle of restorative justice in the approach of case settlement. It is hoped that such restorative justice can create a political balance between the past and the future.
\end{abstract}

Keywords: Human rights, human rights court

\begin{abstract}
Abstrak
Undang-undang tentang Pengadilan HAM telah membawa harapan baru bagi orang-orang tertentu yang menderita karena pelanggaran hakasasi manusia yang terjadi dalam pemerintahan masa lalu (sebelum hukum diberlakukan pada tahun 2000). Tuntutan keadilan tidak hanya fokus pada pelanggaran hak asasi manusia yang terjadi di masa lalu, tetapi juga pada pelanggaran HAM serupa yang akan terjadi di masa depan. Keberadaan Pengadilan HAM permanen tampaknya menyiratkan bahwa hak asasi manusia akan dijunjung tinggi dan dilindungi. Resolusi pelanggaran HAM masa lalu melalui organisasi ekstra-yudisial merupakan langkah maju menuju penyelesaian kasus ini, sedangkan pendekatan konflik dapat digunakan untuk menyelesaikan kasus ini. Keberadaan UU Hak Asasi Manusia memberikan sebuah perbatasan baru dalam melaksanakan prinsip keadilan restoratif dalam pendekatan penyelesaian kasus. Diharapkan bahwa keadilan restoratif tersebut dapat menciptakan keseimbangan politik antara masa lalu dan masa depan
\end{abstract}

Kata kunci : Hak asasi manusia, pengadilan hak asasi manusia

\section{Introduction}

Human Rights are a contentious topic that will continue to be an ongoing subject of discussion. Historically, human rights became a serious topic during the midst of the tumultuous rule of the Monarchical system of government. England began to implement some Human Rights that were written down in 3 manuscripts: the Magna 
Charta (1215), the Habeas Corpus Act (1679) and the Bill of Rights (16891). The American Revolution for Independence gave birth to a number of democratic rights, as implemented in the Virginia Bill of Rights (1776) and the United States Constitution (1787) (as stipulated in Article III, section II (3) of 1789, Amendment Article I-IX; Article XIII, (1865); Article XV (1870); Article XIX (1919)².

The origin of human rights law, as we know today, may be attributed to the establishment of the United Nations. The Charter of the United Nations makes a number of references to human rights. It specifies, in Chapter I entitled "Purposes and Principles", the respect for human rights and fundamental freedoms for all without distinction as to race, sex, language or religion. Elsewhere, the Charter mandates the Economic and Social Council to set up a commission for the promotion of human rights (Article 68). The Commission on Human Rights, since its establishment in 1946 , has served as the organ where the international community, involving primarily the Member States of the United Nations, civil society, and the inter-governmental organizations that create the United Nations system, as we know today, has drafted human rights law.

The main body of international human rights law drafted by the United Nations is known as The International Bill of Human Rights. This term is used to describe the Universal Declaration of Human Rights (adopted in 1948) and the International Covenant on Economic Social and Cultural Rights, the International Covenant on Civil and Political Rights with its two Optional Protocols ${ }^{3}$. The Commission on Human Rights has continued to make a draft of international human rights law and has developed other mechanisms to advance the promotion and protection of human rights. In spite of the existence of international human rights law and the inclusion of similar laws at the national level, serious human rights violations continued to occur.

In the case of Indonesia, severe violations of human rights have been committed systematically as a means of maintaining the government status quo. Considering the significant number of cases of human rights violations, the government decided to establish a Human Rights Court to trial these cases. Law Number 26/2000 regarding the Human Rights Court established this Human Rights Court. Before that, the President, according to his authority, issued a Government Regulation in place of law (PERPU) Number 1/1991 regarding the Human Rights Court. The reform of the court in the context of law enforcement was a significant step in bringing justice to those who seek it.

The background of the implementation of laws regarding the Human Rights Court was connected with the Government of Indonesia's political policy in 1998 when President Habibie announced the referendum in East Timor. This is aimed to obtain a definite resolution of the crisis between the people of East Timor who were pro and anti integration. This resolution had consumed a great deal of the central government's time and put them under international pressure. The decision to hold a referendum resulted in a conflict in the society and finally the international community was invited to participate in observing the referendum. Furthermore, during the post referendum

\footnotetext{
${ }^{1}$ Muhammad Yamin, Proklamasi dan Konstitusi Republik Indonesia (Indonesian Proclamation and Constitution), Ed. V, (Jakarta : Djambatan, 1958), p. 86.

${ }^{2}$ Yamin, supranote 1 .

${ }^{3}$ The International Covenants came into force in 1976. The First Optional Protocol, which makes it possible for individuals to present complaints on violations of human rights to the Human Rights Committee, the body that monitors states' adherence to the Covenant, came into force in 1976. The Second Optional Protocol, on the abolition of the death penalty, came into force in 1991.
} 
period, mass conflict has spread to the point of anarchy between the two groups. This conflict between armed masses and the involvement of a number of members of the Indonesian National Army (Tentara Nasional Indonesia -TNI) ignited international reaction ${ }^{4}$.

The impact of the incidents that occurred during the post referendum period led to the emergence of the Security Council Resolution of the United Nations Number I.319/1999, which assigned the United Nations High Commissioner of Human Rights, Mary Robinson to establish a Fact-Finding Commission in East Timor ${ }^{5}$. The result of the Commission's investigations was a report that pushed Indonesia into the corner. The next step taken by the government was to assign the National Human Rights Commission ("Komnas HAM") to investigate those incidents. At the same time, the Government issued a Government Regulation in lieu to the (PERPU) Number 1/1999 regarding the Human Rights Court. This step was taken as an effort to prevent the Security Council of the United Nations from proposing a resolution to establish an ad hoc Tribunal similar to those that had been established in Rwanda and Yugoslavia ${ }^{6}$.

This government policy has shown a positive result. It has been proven that the Indonesians can show the United Nations that the problem of East Timor can be resolved by Indonesia itself, through the Indonesian legal system, and without any foreign interference. The faith of the international community in the efforts of the Indonesian government to uphold the supremacy of law against human rights violations has improved, through the delivery of the results of the investigation of the case of East Timor by Komnas HAM to the Attorney General. Such faith was further strengthened after the government submitted the draft law regarding the Human Rights Court to amend PERPU 1/1999. The establishment of the Law regarding the Human Rights Court was supported by order as stipulated in Law No. 39/1999 regarding Human Rights ${ }^{7}$.

The enactment of the Human Rights Law on 23 November 2000 implies new hope for the enforcement of human rights in Indonesia. In this law, it is stipulated that the Human Rights Court has the authority to trial severe human rights violations including crimes of genocide and crimes against humanity. In the explanation, it is stated that severe human rights violations stipulated under this law are in accordance with the Rome Statute of The International Criminal Court ${ }^{8}$.

This Essay would gives an overview of the existence of human rights court in Indonesia and discuss some certain issue in related with the court, there are the establishment of the Human Rights Court based on the law 26/2000 regarding Human Rights Court, the court jurisdiction, the enactment of the retroactivity principle in such Law, Witness protection in the court and certain issue in related with the extra judicial mechanism.

\footnotetext{
${ }^{4}$ Romli Atmasasmita, "Human Rights and Human Rights Courts in the Context of Permanent International Courts", one day seminar of "Adjudication of Human Rights Violation by A National, Regional or International Human Rights Court", (Yayasan Hak Asasi Manusia, Demokrasi dan Supremasi Hukum, Jakarta 23 January 2001)

${ }^{5}$ Atmasasmita, supranote 4.

${ }^{6}$ The Indonesian National Commission on Human Rights, Annual Report 1999, (Jakarta : The Indonesian National Commission on Human Rights, 2000).

${ }^{7}$ Besides Law No.39/1999 it was also supported by Law No.5/1998 regarding the Ratification of the Convention against Torture and Law No.29/1998 regarding the Anti Race Discrimination Convention.

${ }^{8}$ The Rome Statute was ratified by the Diplomatic Conference of the United Nations Authorised Embassies on 17 July 1998 in Rome. Because this ratification was carried out in Rome, it was named the Rome Statute. Articles in the Rome Statute which were directly adopted by the Human Rights Law are articles 6 and 7. Indonesia, Law regarding the Human Rights Court, State Gazette Year 2000 No.208, TLN. No.4026
} 


\section{The Establishment of The Human Rights Court}

The existence of the Human Rights Court in the scope of national law was preceded by the birth of Law No.39/1999 regarding Human Rights, particularly article 104 Law No.39/1999 which is as follows:

1. A Human Rights Court will be established within the area of General Judicature in order to trial severe human rights violations.

2. The Court referred to in paragraph (1) will be established by law within a period of a maximum of 4 (four) years.

3. Before the establishment of the Human Rights Court referred to in paragraph (2), cases of human rights violations as referred to in paragraph (1) will be heard by the authorized Court.

According to such directions, the Human Rights Court was established by Law No. 26/2000, which was ratified and enacted on 23 November 2000.

The enactment of Law No. 39/1999 concerning Human Rights is inseparable from the order of the People's Advisory Assembly of the Republic of Indonesia (TAP MPR RI) No.XVII/MPR/1998 regarding Human Rights. The mandate presented by the aforesaid TAP MPR RI was to order the highest state institutions and all government apparatus to respect, enforce and disseminate an understanding of human rights to society ${ }^{9}$.

In order to improve the protection of human rights and develop a situation conducive to the implementation of human rights in line with the Indonesian Ideology of Pancasila, the Indonesian Constitution (UUD) of 1945 and the Universal Declaration of Human Rights, a national commission called the National Commission for Human Rights (Komnas HAM) ${ }^{10}$ was established. Within the framework of increasing the protection of human rights the establishment of Komnas HAM was very strategic. The role of Komnas HAM is to elucidate, examine, observe, research, and mediate on human rights issues, as determined by law ${ }^{11}$.

The existence of Komnas HAM within the framework of observation and reporting of cases of severe human rights violations is strengthening the national legal system in the field of human rights. As part of the law enforcement elements involved in matters of severe human rights violations, Komnas HAM have been legally inaugurated as the sole initial investigator ${ }^{12}$.

The existence of the Human Rights Court within the scope of general judicature implies that in cases that are not determined by Human Rights Law, Law No.2/1986 regarding general judicature will prevail. This is mentioned in article 2 Law No.26/2000, which states that the Human Rights Court is an extraordinary court in the sphere of general judicature. The submission of the Human Rights Court to the general judicature implies that the organizational structure of the Human Rights

\footnotetext{
${ }^{9}$ Article 1 TAP MPR RI No. XVII/MPR/1988.

${ }^{10}$ This statement was in Presidential Decree No.50 year 1993 regarding the National Human Rights Commission, and was then inaugurated by article 105 paragraph 2 point a by Law No.39, 1999.

${ }^{11}$ Article 5 TAP MPR RI No.XVII/MPR/1998.

12 The enactment of Komnas HAM as the sole initial investigator is referred to in article 18 paragraph 1 Law No.26. Indonesia, Supranote 8.
} 
Court is subject to general judicature and not to any other judicature. In addition, article 49 of the Human Rights Law states as follows:

"Regulations regarding the authority of a Superior with the Right to Punish and the Case Delivery Officer as referred to in article 74 and article 123 Law No.31/1997 regarding the Military Court will no longer prevail in the examination of severe human rights violations pursuant to this law"

The abovementioned clause confirms the subjugation of the Human Rights Court to the general judicature. Furthermore there is also clarification in article 1 paragraph 4 Law No.26, which states:

"Every person is individuals, groups of people, civilians, military or police who are responsible as individuals"

The abovementioned clause further confirms that in cases of severe human rights violations there is no submission to any other judicature except to general judicature, nor any recognition of cases of interconnecting jurisdictions. Therefore, it can also be stated that the stipulations concerning interconnecting jurisdictions in Chapter XI of the Indonesian Criminal Law Procedural Code (KUHAP) is invalid in the settlement of cases of severe human rights violations.

It is hoped that the establishment of the Human Rights Court will protect human rights, both of individuals and of groups, and become the basis for law enforcement, legal certainty, justice and a sense of security for individuals and groups against severe human rights violations ${ }^{13}$. The existence of Human Rights Law also implies the expectation of stabilising national unity as aspired to in TAP MPR-RI No.V/MPR/2000 regarding the stability of National Unity.

The existence of Human Rights Law also constitutes an effort by the Indonesian nation to participate in maintaining world peace and ensuring the implementation of human rights ${ }^{14}$, as set forth in the Universal Declaration of Human Rights. As such the establishment of the Human Rights Court is very important, particularly in international relationships where respect for human rights is held in high regard.

\section{Jurisdiction of The Court}

Human Rights violations are set out in Law No.39/1999 regarding Human Rights. In Article 1 paragraph 6 Law No.39 it is stated as follows:

"Human rights violations are all acts by any individual or group of people including the state apparatus which either deliberately or accidentally or as a result of negligence illegally diminish, hinder, restrict, and/or revoke the human rights of any individual or group of people who are guaranteed protection by this Law, and who do not receive or worry that they will not receive fair and appropriate legal settlement, based on the prevailing legal mechanisms."

Article 7 of Law No.26/2000 regarding the Human Rights Court, defines severe violations of human rights as including acts of genocide and crimes against humanity.

\footnotetext{
${ }^{13}$ Explanation Section paragraph VII. Indonesia Supranote 8.

${ }^{14}$ Preamble for point b. Indonesia Supranote 8.
} 
In the explanation section of Article 7 of Law No.26/2000, it is clearly stated that the acts of genocide and crimes against humanity in this stipulation are the same as those in Article 6 and Article 7 of the Rome Statute of The International Criminal Court.

In Law No. 26/2000, Human Rights are clarified as being a set of rights which are part of the essence and the existence of humanity itself as creatures of God who must be respected, held in high regard and protected by the state, the law, the government, and all individuals for the sake of the value and worth of humanity ${ }^{15}$. In the general explanation section of Law No.26/2000, paragraph 6 sub-paragraph 1, it is clearly stated that severe human rights violations are defined as extraordinary crimes with a broad impact at both the national and international level and do not constitute criminal acts as regulated in the Indonesian Criminal Law Code (Kitab Undang-Undang Hukum Pidana - KUHP), and that such acts also cause great damage both materially and immaterially which result in both individuals and communities feeling insecure, and therefore an immediate remedy is required in order to restore the supremacy of law in order to achieve peace, order, harmony, justice and prosperity for all members of society".

Severe human rights violations are not merely legal matters but also have political dimensions that are different than ordinary crimes. The settlement of cases of severe violations of human rights must represent both of these dimensions. Thus the limitations of severe violations of human rights are not just based on law alone, because if they were based on law alone they could not be amended like ordinary crimes. The inclusion of political dimensions is what gives severe violations of human rights their own individual characteristics and thus they are considered as main focus in every state. General explanation of the law has categorized the crimes that have been mention in the law as extraordinary crimes. ${ }^{16}$

The classifications of the two types of severe violations of human rights are described in Article 8 and Article 9 Law No.26/2000 concerning the Human Rights Court. Acts of genocide are classified in Article 8 Law No.26/2000, which states as follows:

"Crimes of genocide as determined in Article 7 paragraph (a) are any acts performed for the purpose of annihilating or eliminating an entire or part of a national or ethnic group, race or religion, by means of:

a. Killing members of the group;

b. Causing serious physical or mental harm to members of the group;

c. Deliberately inflicting on the group living conditions calculated to bring about its physical destruction in whole or in part;

d. Imposing measures intended to prevent birth within the group; or

e. Forcibly transferring children from certain groups to other groups."

Crimes against humanity are classified in Article 9 Law No.26 year/2000, which states as follows:

"Crimes against humanity as determined in Article 7 paragraph $b$ are any acts that are performed as part of a widespread or systematic assault whereby it is known

\footnotetext{
${ }^{15}$ Article 1 paragraph 1 . Indonesia Supranote 8.

${ }^{16}$ General Explanation. Indonesia Supranote 8.
} 
that such assault is aimed directly at the civilians ${ }^{17}$, such as:
a. Murder ${ }^{18}$;
b. Extermination ${ }^{19}$;
c. Enslavement ${ }^{20}$;
d. Deportation or forced movement of citizens ${ }^{21}$;

e. Expropriation of independence or expropriation of other physical liberties in an arbitrary manner which goes against the principles of the stipulations of international law;

f. $\quad$ Torture $^{22}$;

g. Rape, sex slavery, forced prostitution, forced pregnancy, forced sterilization or other similar sexual violations;

h. Persecution of a specific group or organization based on their politics, race, nationality, ethnicity, culture, religion, sex or other reason universally acknowledged as a prohibited action pursuant to international law;

i. $\quad$ Forced disappearance of people ${ }^{23}$;

j. Apartheid crimes. ${ }^{24 "}$

A member of a group referred to in Article 8 paragraph a Law No.26/2000 means one or more members of a group. In Article 8 Law No.26/2000 the number of victims of genocide is not important, what is important is the intent of the acts concerned. This is in line with the implementation of Indonesian Criminal Law, whereby the number of victims is not the focus of the classification of the criminal act concerned, but rather the intention of the act concerned to cause destruction or annihilation.

\section{The Enactment of Retroactivity Principle in The Law of Human Rights Court in Indonesia}

In the framework of enforcing human rights law several legal principles are adopted. Those principles are explicitly described in the Articles of Law No.26/2000. The

17 "Assault aimed directly at the civilians" means a set of activities carried out on civilians as a continuation of the policy of the authorities or policy which is related to an organization (see explanation section of Article 9 ). Indonesia Supranote 8.

${ }^{18}$ Murder here is as set forth in Article 340 of the Indonesian Criminal Law Code. Indonesia Supranote 8.

${ }^{19}$ Extermination includes acts that cause suffering which are carried out deliberately, and includes the delay of food and medical supplies, which may result in the annihilation of civilians. Indonesia Supranote 8.

${ }^{20}$ Enslavement here includes trade in humans, particularly the trade of women and children. Indonesia Supranote 8.

${ }^{21}$ Deportation or forced transfer of residents means the forced transfer of people via exile or other forceful acts from the area where they validly live, without any basis permitted by international law. Indonesia Supranote 8.

${ }^{22}$ Torture in this stipulation means deliberately or illegally causing serious pain or suffering, whether physically or mentally, of prisoners or people under supervision. Indonesia Supranote 8.

${ }^{23}$ Forced disappearance of people means the arrest, detention or kidnapping of a person by or with the authorization, support or approval of the state or of an organization's policy, followed by the refusal to admit to the expropriation of freedom or to provide any information regarding the fate or condition of the person concerned, with the purpose of keeping them from the protection of the law for a long period of time. Indonesia Supranote 8.

${ }^{24}$ Apartheid crimes are inhuman acts the same as those described in Article 8, which are conducted in the context of an institutional regime in the form of oppression or domination by a certain group or groups of other races for the purpose of maintaining that regime. Indonesia Supranote 8. 
principles described in Law No.26/2000 are identical to the principles of the Indonesian Criminal Law Code.

The legitimacy of the Human Rights Court's authority to trial human rights cases is set out in Article 4 Law No.26/2000. With an acknowledgement of authority to trial cases of severe human rights violations, there are specific rules concerning criminal acts other than those criminal acts that are already regulated in the Indonesian Criminal Law Code.

As a specific law that regulates human rights offences and the legal proceedings for those offences, Law No.26/2000 concerns both material offences and formal offences. In addition, as a law concerning specific criminal acts, there are exceptions to principles that are generally included in the Indonesian Criminal Law Code (KUHP) or the Indonesian Criminal Law Procedural Code (KUHAP). These exceptional are that as long as not otherwise determined by Law No.26/2000 then the general criminal law prevails, thus in this case the principle of Lex Specialis derogat Legi Generalis is valid.

The validity of the Lex Specialis derogat Legi Generalis principle, must fulfil the following criteria:

a. Exceptions to the general law are implemented by regulations of the same level as the law concerned.

b. The exception concerned is clarified in that particular law. Thus the exception is only valid to the extent that it is clarified and the part that is not excluded is still valid as long as it does not contravene the implementation of that particular law ${ }^{25}$.

According to Human Rights Law there is no impunity ${ }^{26}$ for perpetrators of severe human rights violations whether those perpetrators are military personal or civilians. This loss of impunity is clarified in Article 42 Law No.26/2000, which states as follows:

1) A military commander or someone effectively acting as a military commander can be held responsible for a criminal act committed within the jurisdiction of the Human Rights Court, which are committed by soldiers effectively under their command or control, or effectively under their authority and control and the criminal act concerned was a result of improper control of troops, that is:

a. The military commander or aforementioned person knew or based on the situation at the time should have known that those troops were committing or had just committed a severe human rights violation; and

b. The military commander or aforementioned person did not take the appropriate and necessary actions within the scope of their authority to prevent or stop the act or to deliver the perpetrator to the authorities to be questioned, investigated and charged.

2) A superior whether a policeman or other civilian:

a. The superior knew or deliberately ignored information which clearly showed that their subordinates were committing or had just committed a severe human rights violation; and

\footnotetext{
${ }^{25}$ Sudikno Mertokusumo, Mengenal Hukum (Suatu Pengantar), (Know the Law (An Introduction)) 1st edition. (Yogyakarta: Liberty, 1996).

${ }^{26}$ Impunity is an exemption from punishment (The New Webster Dictionary, Op. Cit.)
} 
b. The superior did not take the appropriate and necessary action within the scope of their authority to prevent or stop the act or to deliver the perpetrator to the authorities to be questioned, investigated and charged.

3) Any act as mentioned in paragraph (1) and paragraph (2) is liable to the same punishments as those described in Article 36, Article 37, Article 38, Article 39, and Article 40.

In Law No.26/2000, Article 43 paragraph (1) states as follows:

"Severe human rights violations, which occurred before this law was enacted, will be investigated and judged by the Ad Hoc Human Rights Court"

Pursuant to this clause it is clear that Law No.26/2000 adopts the retroactive principle. The enactment of a law for settling past human rights violations clearly contravenes the non-retroactive principle as set forth in Article 1 paragraph 1 of the Indonesian Criminal Law Code ${ }^{27}$.

The enactment of the retroactive principle for severe human rights violations is not a deviation in view of international law practices ${ }^{28}$. The same deviation occurred when the Nuremberg and Tokyo trials were held for World War II war criminals in 1946 and $1948^{29}$. In fact, the principles of the Nuremberg trials have been acknowledged as the international norm. Those international law practices were followed up and authenticated by the establishment of an ad hoc Tribunal for the ex-colonies of Yugoslavia (1993) and an ad hoc Tribunal for Rwanda (1994) ${ }^{30}$.

The enactment of the retroactive principle in Law No.26/2000 has caused a constitutional dilemma. This is because in Article 28 I Amendment II of the Indonesian Constitution (Undang-Undang Dasar - UUD) 1945, it is stated that retroactive principles cannot be enacted. However the stipulations of the constitution are answered by Article 28 J Amendment II of the Indonesian Constitution, 1945, which states as follows:

"In enjoying their rights and freedoms every individual is subject to the limitations stipulated by the law in order to ensure the acknowledgement and respect of the rights and freedoms of others and in order to fulfil the just demand for consideration of morality, religious values, security, and public order in a democratic society"

The abovementioned Article $28 \mathrm{~J}$ states that every citizen is subject to the limitations stipulated by the law. In other words, the retroactive principle was legally enacted in order to protect human rights.

Another reason for the enactment of the retroactive principle for past human rights

${ }^{27}$ The problem of the contradiction of the retroactive principle is also stated in Article 18 paragraph 2 Law No.39 year 1999 regarding human rights, where it is stated that "no person can be charged and punished for a crime, except on the basis of laws and regulations which were already in existence before the crime was committed". The issue of legality in criminal law is often used as a reason to reject the authority of the ad hoc human rights court to investigate, hear and judge cases of human rights violations, by the legal advisors of the defendant in the ad hoc human rights court. The information comes from interviewed with Widodo Supriyadi (Prosecutor of Attorney General Office), interviewed held in 22nd of May, 2012 at Attorney General Office.

${ }^{28}$ General Explanation section. Indonesia Supranote 8.

${ }^{29}$ Atmasasmita, Supranote 4.

${ }^{30}$ United Nations, Basic Facts About the United Nations, (New York: Department of Public Information United Nations, 1998), page.269. 
violations is based on a consideration of morality, religious values, security and public order in a democratic society in the name of justice. The enactment of the retroactive principle for the purpose of enforcing the law in cases of past severe human rights violations is more based on political considerations. This situation occurred because during the transition process from an authoritarian government to a democratic government a middle road is required in order to resolve national crisis, and for the sake of political stability.

The aforementioned political reasons do not mean an abandonment of juridical procedures, because the existence of Human Rights Law means that juridical procedures are very important. Consideration of political issues occurs because severe human rights violations that have occurred in the past cannot be separated from the scope of previous government political policy. It is undeniable that human rights violations that have occurred in various parts of the world are inseparable from the politics behind those acts.

The enactment of the retroactive principle as stated in Article 43 paragraph 1 Law No.26/2000, still leaves us with a significant legal problem, which is the time limit for the effectiveness of the retroactive principle. The enactment of the retroactive principle without any time limits will give rise to fluctuating interpretations of this principle. Because without any time limit for past severe human rights violations, it can be said that the past referred to begins at the time of Indonesian independence and goes until 23 November 2000.

The establishment of Law No.26/2000 concerning the Human Rights Court was intended to provide legal certainty, however the enactment of the retroactive principle without any time limits may cause legal uncertainty. Some people may respond to the above statement by referring to the existence of the expiration principle in the Indonesian Criminal Law Code, however in Human Rights Law the expiration principle is not enacted pursuant to criminal law. This matter is clarified in Article 46 of the Human Rights Court law, which states as follows that for severe violation of human rights as set forth in this law the expiration principle is not valid.

The existence of this clause confirms that there is no definitive time limits for past human rights violations. The enactment of a time limit is very important for legal certainty in enforcing the law in cases of past severe human rights violations. Thus, there are needs to be a time limit for the "past" meant by the law, whereby this is regulated in an amendment to Human Rights Law.

However, along with the movement of time and the need for legal certainty concerning the aforementioned time limit, in the opinion of this writer, Article 43 paragraph $2^{31}$ Law No.26/2000 must be implemented effectively. The time limit for past severe human rights violations can be determined by the National Commission of Human Rights (Komnas HAM) after sorting through those cases at the time that the reports of those human rights violations are submitted to Komnas HAM. Thus the sorting out and determination of the time limit can be carried out by both those organizations as well as the executives.

\footnotetext{
${ }^{31}$ Article 43 paragraph 2 states that "the ad hoc human rights court as mentioned in paragraph 1 was established at the request of the Indonesian Legislative Assembly based on certain events and by Presidential Decree". Indonesia Supranote 8.
} 


\section{Reviewed on Witness Protection in The Human Rights Court}

Law No. 26/2000 grants special rights to witnesses and victims of severe human rights violations that are not regulated in KUHAP, which is the protection of such witnesses and victims. The need for witness protection is very important although in reality no witnesses have experienced physical attack or direct threats. However without witness protection, witnesses can experience fear and difficulties in providing testimony.

Law No.26/2000 concerning the Human Rights Court, pursuant to Article 34 Law No. 26/2000, grants victims and witnesses physical and mental protection from threats, interference, terror, or violence from any party. Witnesses and victims play an important role in the evidential process in trials, and it is important that no agents suspected of seriously violating human rights can intimidate witnesses ${ }^{32}$. By providing protection it is hoped that both victims and witnesses can provide truthful information, and that the trial process for cases of severe human rights violations can run smoothly. Further procedures for witnesses' protection are regulated under Government Regulation No. 2/2002 regarding Procedures for the Protection of Victims and Witnesses of Severe Human Rights violations ${ }^{33}$.

Any witness or victim of severe human rights violations has the right to obtain protection from the law enforcement apparatus and security apparatus ${ }^{34}$, which is given from the phases of preliminary investigation, investigation, prosecution and or examination before the court ${ }^{35}$. The protection of victims and witnesses includes protection of personal safety from physical and psychological threat, confidential identity, and providing information at the examination before the court without coming face to face with the suspect ${ }^{36}$.

The protection of witnesses and victims can be implemented in two ways, firstly, protection based on the initiative of the law enforcement apparatus; secondly, protection based on the request of the victims and witnesses ${ }^{37}$. Such requests can be made to Komnas HAM at the phase of initial investigation, to the Attorney General at the phase of prosecution, and to the court at the phase of examination. The victim or witness can make such a request directly to the security apparatus ${ }^{38}$. One source is of the opinion that the protection of witnesses and victims in the Human Rights Court is not sufficiently regulated in a government regulation and that if law regulated it then it would hold more force ${ }^{39}$, and unfortunately the government regulation is not

\footnotetext{
${ }^{32}$ National Human Rights Commission, Report on International Workshop "Crimes Against Humanity", Komnas HAM, Jakarta 20th-21th June 2001.

${ }^{33}$ Compare with ICC's witness protection. In ICC, a special unit was formed by The Registrar whereby witness protection is the full responsibility of this special unit and independant of the responsibilities of the general prosecutor, Judge and legal advisor. The special unit is responsible for administrative and technical issues for witnesses appearing before the court and for various other appearances, to secure the safety, integrity, and dignity of witnesses and victims including any issues relating to gender and culture. (Subsection 2, Prepatory Commission for The International Criminal Court).

${ }^{34}$ Indonesia, Peraturan Pemerintah Tentang Tata cara Perlindungan Terhadap korban Dan Saksi Dalam pelanggaran Hak Asasi Manusia Yang Berat (Government Regulations Concerning Procedures for Protection of Victims and Wintesses of Severe Human Rights Violations), PP No. 2/2002, LN No. Year, TLN. No. 4171. art. 2 section (1).

${ }^{35}$ Article 2 section (2). Indonesia, supranote 34

${ }^{36}$ Article 4. Indonesia, supranote 34

${ }^{37}$ Article 5 sec (1). Indonesia, supranote 34

${ }^{38}$ Article 5 sec (2). Indonesia, supranote 34

${ }^{39}$ Interviewed with Widodo Supriyadi (prosecutor of Human rights at Attorney General Office), dated
} 
completed by security procedures ${ }^{40}$.

Moreover, to overcome issues of witness and victim protection it is proposed that a special witness and victim protection unit be established. ${ }^{41}$ This witness and victim protection unit would have the task of providing protection to witnesses and victims from the phases of preliminary investigation, investigation, prosecution, and examination before and after the court hearing. The witness and victim protection unit would also have the responsibility of protecting witnesses and victims from suffering for a second time and ensuring that they do not experience structural victimization. For example, when a witness has to travel to an area they do not know, appear before a foreign court, follow unfamiliar procedures, and undergo examination of their testimony. In addition, the special witness and victim protection unit would also be responsible for preparing the witness materially, physically and psychologically to be stand before the court.

However in establishing a witness and victim protection unit, care must be taken concerning whose authority this unit is under ${ }^{42}$, and who has the right to be a member of the witness and victim protection unit, in order that witnesses who are to give their testimonies are not too scared to come before the party authorized to protect them. In addition, it needs to be remembered that the protection to be provided is not only protection of physical safety but also psychological protection, thus as well as ensuring security people are needed who have specific abilities in providing physiological protection.

The establishment of a special witness and victim protection unit certainly requires large amounts of funding; however it is possible to shift the burden of establishment and operational costs of the protection unit to the government through the State Income and Expenditure Budget (APBN). In addition to problems of witness and victim protection, there must be consideration of the protection of all law enforcement apparatus in the human rights court, including the Judges, general prosecutor,

\section{2nd of May 2012.}

${ }^{40}$ Progress Report 3 ELSAM on the Ad Hoc Human Rights Court, East Timor case, ELSAM 2002, page 10.

${ }^{41}$ The importance of establishing a witness protection unit was supported by Widodo Supriyadi based on his experience in bringing witnesses from East-Timor before the court as he explained in interviewed on 22nd May 2012, that is; Before calling a witness, the general prosecutor first made an inventory of all witnesses from East-Timor to be called, then the Minister of Finance calculated the cost of bringing out those witnesses. After arriving at the airport, the witnesses were collected by the local district attorney. However, there was a problem with a witness who was proposing to oppose suspects who were members of TNI (Indonesian Army) as after being collected from the airport the witnesses stayed overnight at Jl. Denpasar under the supervision of the TNI advocacy team. It is not known what occured after the general prosecutor left. However, when the examination began the testimony given was different from the testimony given during the intitial investigation in East-Timor. I am not saying that it was made up or that there was any pressure bought to bear but those are the facts. The budget allocated to present the witnesses from East-Timor that was derived from state money issued by the Minister of Finance was all in vain. We were confident about presenting a witness from East Timor because we were certain that their testimony would strengthen the evidence, however during the examination before the court their testimony was different than that given at the first examination before the UNTAET officers. In light of this incident we concluded that we strongly support the protection of witnesses and victims. Supranote 39.

${ }^{42}$ Lies Sugondo (retired Komnas HAM member) was pessimistic about establishing a witness and victim protection unit under Komnas HAM because it would add to the burden of responsibilities of Komnas HAM and he feared that this would not be balanced by additional staff and funds, and in addition Komnas HAM do not have the forces to carry out such duties. Masyarakat Pemantau Peradilan Indonesia, The Annotation of the Judicial Decission regarding The Human Rights Court Panel Judges Decission on East Timor Case, 2003. 
advocate and police, and also members of Komnas HAM who carry out their duties in the Human Rights Court, since it is not only witnesses and victims whose lives are threatened, law enforcers are also concerned about their personal safety ${ }^{43}$.

\section{VI.Extra Judicial Mechanism: From Truth Reconciliation Commission to the Islah Mechanism in Tanjung Priok Case.}

Human Rights Law determines that both judicial mechanisms and extra judicial mechanisms will be established, extra-judicial mechanisms take the form of a Truth and Reconciliation Commission. The Truth and Reconciliation Commission has the task of enforcing truth by revealing past misuses of power and human rights violations, in accordance with the valid laws and regulations and to implement reconciliation from the perspective of the nation's joint interests ${ }^{44}$.

The settlement of cases of human rights violations that occurred in the past is not easy, particularly if settlement is conducted through judicial mechanisms or by bringing the perpetrator before the court. Difficulties that may arise are in the gathering of evidence including witnesses, victims, or articles of evidence that may be used to catch the perpetrator. These difficulties should be able to be eliminated if past human rights violations are viewed as a lesson to the entire nation not to conduct similar violations in the future. The Truth and Reconciliation Commission could be the answer to consolidating national unity in order to build a future and forget the past.

Based on the abovementioned explanation, the focus of the Truth and Reconciliation Commission will be the investigation of past human rights violations. Even though the law has legitimized the use of the retroactive principle to settle human rights violations, experts consider that the retroactive principle should be given a strict time limit. However, it is still proving difficult to find specific factors for limiting this time frame. The settlement of cases through Truth and Reconciliation Commission could reduce political friction that could prolong the settlement of cases if taken to court. Furthermore a special investigation is required to investigate whether an incident in the past constitutes severe human rights violations or not. Investigations of severe human rights violations have a higher degree of difficulty than the investigations of ordinary criminal cases.

The difficulty of conducting aforementioned investigations is evident from the fact that when an incident of severe human rights violations has occurred in the past it is highly likely that the evidence has already disappeared, been damaged, or is difficult to find because the conditions of the field of investigation at the time the incident occurred and the conditions at the time of the investigation are very different. Consequently the investigation of severe human rights violations requires special procedures. These include investigation procedures and special authority being granted to Komnas HAM.

Amnesty shall be granted as in return for revealing the truth of an incident of severe

\footnotetext{
${ }^{43}$ As stated by Andi Samsan Nganro (Supreme Justice at Supreme Court, was former Human Rights Court Judge for East Timor and Tanjung Priok Case) on the Interviewed that was held in 7th of June, 2012 at Supreme Court Office, Jakarta.

${ }^{44}$ Final paragraph of General Explanation, Law No. 26/2000 regarding The Human Rights Court. In addition, the establishment of the Truth and Reconciliation Commission is also mentioned in the People's Advisory Assembly (MPR) Decree Number V/MPR/2000 on the Consolidation of National Unity. Indonesia Supranote 8.
} 
human rights violations. Amnesty shall only granted if when the perpetrator reveals the truth; their confession and apology are accepted by the nation. In the event that the Head of State does not grant amnesty, then requests for compensation and rehabilitation will not be viable and only restitution is possible as it concerns the relationship between individuals and not with the state.

The concept of the Truth and Reconciliation Commission in South Africa is a concept used by the Christians called absolution ${ }^{45}$. The most important duty of the Truth and Reconciliation Commission is to discover the facts, when, where, who the perpetrators are, and who the victims are. In this Commission a person who testifies or confesses to a criminal act that has been committed in a complete and detailed manner is then granted amnesty or absolution ${ }^{46}$ as a reward for revealing the truth. This is the basis for the birth of a new order of Reconciliation ${ }^{47}$.

The settlement of cases of past severe human rights violations through Truth and Reconciliation Commissions is an effort to implement Restorative Justice. Restorative Justice is a basic framework for regulations concerning the victims of crime, which demand changes to the understanding that criminal law violations are violations of the rights of victims of crime, as well as violations of public and state interests ${ }^{48}$. Existential admissions and the legal position of victims of crime in the criminal justice system are mechanisms for conflict resolution by the provision of restitution, compensation and rehabilitation as part of criminal law and punishment.

Acknowledgement of the rights of victims is very important to the settlement of cases of past severe human rights violations, in which the victim is given the opportunity to speak and receive an explanation regarding major incidents of human rights violations that occurred ${ }^{49}$.

The concept of the Truth and Reconciliation Commission has been applied in South Africa and several other countries; nonetheless the implementation of this Commission in Indonesia still requires in-depth study to adjust it to the characteristics of human rights violations in Indonesia. The importance of understanding the application of the concept of the Truth and Reconciliation Commission can be seen in the Tanjung Priok case. Try Sutrisno attempted to settle the matter by holding an islah (Islamic mechanism of dispute settlement) with the victims and the victim's families.

The islah method proposed by one of the victim to Try Sutrisno ${ }^{50}$ who was the Military

\footnotetext{
${ }^{45}$ H.M. Dandala, in "Role of The Religious Communities in Bringing Reconciliation in South Africa", (the paper was delivered at an International Conference: National reconciliation: Learning from the Experience of South Africa, Jakarta, 22nd March 2001), page 2.

${ }^{46}$ In the Law of the South African Truth and Reconciliation Commission (The Promotion of Unity and Reconciliation Act 1997), it was stated in the preamble "...the garnating of amnesty to persons who make full disclosure of all the relevant facts relating to acts associated with political objectives committed in the course of conflicts of the past during the said period (1st March 1960 - 6th December 1996)..."

${ }^{47}$ Reconciliation means an adjustment, or to bring together two things which differ one from the other so that they can now agree and be as one. (Webster Dictionary,Op.Cit.)

${ }^{48}$, "Posisi Hukum Korban Kejahatan dalam Sistem Peradilan Pidana," (The Legal Position of Victims of Crime in the Criminal Justice System) (Doctoral dissertation, University of Indonesia, Jakarta, 2001).

${ }^{49}$ International Crisis Group, “ ICG Asia Report on Indonesia: Impunity Versus Accountability for Gross Human Rights Violations," (Jakarta, 2 February 2001), page 26.

${ }^{50}$ This is as mentioned by Syarifuddin Rambe in the interviewed that held in 10 of May, 2012 at his house in Tanjung Priok. He mentioned that on the meeting with Try Sutrisno, he explained about the initiative to make an Islamic settlement called Ishlah and proposed Nurcholish Madjid (prominent scholar and Ulama) to be a mediator between victims and military officer at that time of incident occurred, Ishlah mechanism is the way to reconcile all actors in Tanjung Priok 1984, and not to be a such of commodity for
} 
Commander of the Greater Jakarta Region at the time of the Tanjung Priok tragedy, has not solved the problem from a legal aspect, however it is a possible option if based on Human Rights Law whereby the method of dispute settlement opened up is a judicial mechanism as explained above. Although in fact islah is one of the dispute settlement methods, which can be offered in Islam to break the ice between the parties concerned as a result of a specific incident, that has distanced those parties. Nurcholish Madjid stated that islah is a middle road as well as a humanitarian option ${ }^{51}$.

Theoretically what Try Sutrisno did was not just an islah, it was also heading in the direction of an afwun ${ }^{52}$. This is because in the meeting between the victims and successors of the victims with Try Sutrisno and his colleagues, there was a statement of pardon from the victims and successors of the victims of the Tanjung Priok incident. In Islam afwun is explained in the Al Qur'an Surah al-Baqarah verse 178 (Qs. 2:178) that states as follows:

Hey faithful people! You are obliged to qishash ${ }^{53}$ in cases of murder; free people for free people; servants for servants; and women for women. Whosoever is granted a pardon by the relatives of the person murdered, that those parties who grant the pardon, while the pardoned party must pay diyat to the pardoning relatives in the proper manner must properly adhere to pardon. As such, this is a lighter sentence that has been declared by your Lord, whilst for you it is also a blessing. Whoever violates it afterwards, will be severely punished.

It is clear that the pardoning of qishash must be accompanied by a payment of diyat to the victim or to the victim's family. In addition, in afwun the principles and conditions that have been stipulated must be fulfilled. According to fuqaha or experts of fiqh (Islamic Study of laws pertaining to ritual obligations), the principle of afwun is a statement by beneficiaries of the victim that pardons the perpetrator of the murder. The utterance of the pronouncement concerned does not have to be a specific pronouncement, but a granting of pardon such as 'I forgive him', 'I call off the qishash on him', or 'I liberate him'54.

The requirement of afwun according to fuqaha is that the person granting the pardon is an adult and in their right mind, and that the pardon is granted by a person with the right to grant that pardon. There are differences of opinion between the Maliki mazhab (particular school of thought concerning Muslim law) and other jumhur ulama fiqh (major groups of Muslim scholars) concerning the people who have the right to grant a pardon. The Maliki believe that the only people with the right to grant a pardon are male beneficiaries with ashabah ${ }^{55}$ status, while other Muslim scholars believe that both male and female beneficiaries of the person murdered have that right ${ }^{56}$. Thus

certain people or group by raising this issues all the times, we want to live in peace and give our pardoned for the all happened in the incident, Rambe said in the interviewed.

51 "Pesan Moral dari Islah Try Sutrisno dan Korban Kasus Tanjung Priok" (The Moral Message of the Islah between Try Sutrisno and Victims of the Tanjung Priok Case), Kompas, 9 March 2001

${ }^{52}$ Etymologically, afwun means vanish or erase; pardon. In fiqh this term is discussed in relation to the issue of punishment for murder (Jarimah fi' qishash). See, Dahlan, Abdul Aziz. (1996). Ensiklopedi hukum Islam. Jakarta : Ichtiar Baru van Hoeve, page 30.

${ }^{53}$ Qishash means punishing murderers with the death penalty (Bachtiar Surin, Terjemah dan Tafsir AlQur'an (Translation and Interpretation of the Koran), (Bandung: Fa. Sumatra, 1978), page 55.

${ }^{54}$ Dahlan, supranote 52 , page. 30.

${ }^{55}$ Ashabah means a group of people that are patrilineal blood relatives who obtain an unspecified or open portion (see Sajuti Thalib (1987), Hukum Kewarisan Islam di Indonesia (Law of Inheritance in Indonesia), Jakarta: Bina Aksara, page 113 - 114.

${ }^{56}$ Dahlan, supranote 52 , page 30. 
the principles and requirements of afwun in Islam are clear, and the actions of Try Sutrisno towards the victims and their beneficiaries must fulfill those requirements.

The actions of those parties does not remove the crime that was committed, because based on the prevailing rules and regulations concerning those acts, there are predetermined mechanisms for settlement. Therefore such actions do not stop legal proceedings from being conducted against the perpetrators of severe human rights violations in the Tanjung Priok tragedy of 1984 . However, the parties concerned as a basis for imposing lighter sentences may put those actions forward. This is because the settlement mechanisms for past severe human rights violations have been definitively determined by law, including the extra judicial mechanisms. Consequently, the measures taken by the parties concerned were political measures cloaked in legal discourse. In this case only political settlement according to Islamic law was achieved, and not settlement according to positive law, whereby Islah is equated with the Truth and Reconciliation Commission as set forth in Law No.26/2000. The authors of this report are of the opinion that Islah cannot be equated with the Truth and Reconciliation Commission. If Indonesia wishes to implement the concept of this Commission then further in-depth studies on this are required, because every human rights violation, which occurs must be handled using different mechanisms as the specific characteristics of each case are also different.

Even though settlement through islah was carried out, this did not eliminate the criminal acts that had been committed, because mechanisms for the settlement of such acts have already been determined in the prevailing laws and regulations. On the one hand this did not stop court proceedings from being applied to the perpetrators of severe human rights violations in Tanjung Priok in 1984. In fact, court has acknowledged the Islah in their decisions and put it as one of the good efforts then sentenced the defendant with the minimum sentenced. In court, there is many witnesses has change their summoned and forgive the defendant or asked the panel judges to liberate the defendants. This happened because of the process of islah being implemented and gives a good side effect to the victims and their family, such as house, employment and scholarships for their children until they earned the bachelor degree.

\section{Conclusion}

The enactment of the Human Rights Law has opened a new page in the enforcement of the supremacy of law against human rights violations, not excluding human rights violations, which occurred in the past. The transition from a military government towards a democratic government must be accompanied by the protection of human rights. This transition has brought to the surface all manner of past repressions by the government apparatus.

The demand to bring to justice various severe human rights violations' occurring in the past has made the nation remembers the tragedies of those times. One of the demands of victims, the families of victims and other sympathetic parties is that action should be taken against those who have violated human rights in the past. During this transition period, these people demand justice. The demand for justice does not only focus on human rights violations, which occurred in the past but also similar human rights violations that will occur in the future. The existence of a permanent Human Rights Court seems to imply that human rights will be upheld and protected. Cases of 
severe human rights violations that occurred in the past should be resolved through the ad hoc Human Rights Court and the Truth and Reconciliation Commission.

The enforcement of the law against past human rights violations stresses the function of intimidation. Pursuant to the prevailing laws during those times, the valid criminal material is the Indonesian Criminal Law Code (KUHP). The implementation of a retroactive principle for violations of human rights that occurred in the past causes conflict with the KUHP, which has a non-retroactive principle.

The changes of perception concerning enforcing the law against severe human rights violations imply hope as well as bringing up queries and conflict. Indeed, there is an international tendency towards changes in the perception of enforcing criminal law, whereby via ad hoc tribunals, human rights violations which occurred during World War II can be tried. In a similar manner an Ad hoc Tribunal for former Yugoslavia and an Ad hoc Tribunal for Rwanda were established.

The mechanisms for resolving cases of human rights violations being proposed will improve if they are firmly committed to justice. The resolution of past human rights violations via a conflict approach is preferable for the national reconciliation. An attitude of looking further to the future of development via national reconciliation is the method proposed for this stage of governmental transition. This concept was successfully carried out in South Africa, and gave birth to the national reconciliation.

The resolution of past human rights violations through extra-judicial organizations is an advanced step towards resolving the case, whereas a conflict approach can be used to settle the case. The existence of the Human Rights Law provides a new frontier in implementing the principle of restorative justice in the approach of case settlement. It is hoped that such restorative justice can create a political balance between the past and the future.

\section{Bibliography}

Amstutz, M.R. (2005). The Healing of Nations. Lanham: Rowman \& littlefield.

Andrews, S., Tombokou. (2008). Doing Narrative Research. Los Angeles, London, New Delhi, Singapore, SAGE.

Arinanto, Satya. (2005). Hak Asasi Manusia dalam Transisi Politik di Indonesia [Human Rights in Indonesia's Political Transition]. Jakarta: Pusat Studi Hukum Tata Negara Fakultas Hukum Universitas Indonesia.

Atmasasmita, Romli.(2001). "Human Rights and Human Rights Courts in the Context of Permanent International Courts", one day seminar of "Adjudication of Human Rights Violation by A National, Regional or International Human Rights Court", (Yayasan Hak Asasi Manusia, Demokrasi dan Supremasi Hukum, Jakarta 23 January 2001)

Bachtiar Surin. (1978). Terjemah dan Tafsir Al-Qur'an (Translation and Interpretation of the Koran), Bandung: Fa. Sumatra.

Bassiouni, C. (2002) (ed.), Post-Conflict Justice. Ardsley: Transnational Publishers

Bloor, M. (2001). Frankland, J, Thomas,M, Robson,K. Focus Group in Social Research. New Delhi, SAGE Publication California.

Connelly, F. M. (2000). Clandini, J.D. Narrative Inquiry: Experience and Story in Qualitative Research. San Fransisco, Jossey-Bass.

Dahlan, Abdul Aziz. (1996). Ensiklopedi hukum Islam. Jakarta : Ichtiar Baru van 
Hoeve,

El-Muhtaj, Madja. (2005). Hak Asasi Manusia dalam Konstitusi Indonesia Dari UUD 1945 sampai dengan Amandemen UUD 1945 Tahun 2002. Edisi I, cet ke-2, Jakarta: Kencana Prenada Media Group.

ELSAM, et.al. (2011). Pengadilan Yang Melupakan Korban. 2004. Kelompok Kerja Pemantau Pengadilan HAM, ELSAM, KontraS dan PBHI, 24 Agustus 2006 as cited in http://elsam.or.id/downloads/1272273131_11.tindak-pidana-ham_5. pdf. last accessed 24 November 2011.

. (2002). Progress Report 3 ELSAM on the Ad Hoc Human Rights Court, East Timor case, ELSAM 2002.

Farid, Hilmar and Rikardo Simarmatra. (2004). The Struggle for Truth and Justice: A Survey of Transitional Justice Initiatives Throughout Indonesia, Occasional Paper Series. New York: ICTJ.

H.M. Dandala. (2001). "Role of The Religious Communities in Bringing Reconciliation in South Africa", (the paper was delivered at an International Conference: National reconciliation: Learning from the Experience of South Africa, Jakarta, $22^{\text {nd }}$ March 2001).

Hadiprayitno,Irene Istiningsih. (2010). Defensive Enforcement: Human Rights in Indonesia Hum Rights Rev 11:373-399.

Hayner, P. (1994) Fifteen truth commissions, 1974-1993: A comparative study. Human Rights Quarterly, XVI, str. 600-655

(1994) Fifteen truth commissions, 1974-1993: A comparative study. Human Rights Quarterly, XVI, str. 600-655

(2011). Unspeakable Truth: Transistional justice and the Challenge of Truth Commissions, Routledge: New York.

Indonesia. (2000) Law regarding the Human Rights Court, State Gazette Year 2000 No.208, TLN. No.4026.

. (2000) Peraturan Pemerintah Tentang Tata cara Perlindungan Terhadap korban Dan Saksi Dalam pelanggaran Hak Asasi Manusia Yang Berat (Government Regulations Concerning Procedures for Protection of Victims and Wintesses of Severe Human Rights Violations), PP No. 2/2002, LN No. Year, TLN. No. 4171. art. 2 section (1).

Indonesian Human Rights Commission. (2001). Report on International Workshop "Crimes Against Humanity", Komnas HAM, Jakarta $20^{\text {th }}-21^{\text {th }}$ June 2001,

International Center for Transitional Justice (ICTJ) defines some elements in regard with the transitional justice policy that should be taken for country with repression or HR violation records. Taken from from ICTJ website http://ictj. org/about/transitional-justice, last accessed 11 January 2012.

International Crisis Group. (2001). "ICG Asia Report on Indonesia: Impunity Versus Accountability for Gross Human Rights Violations," (Jakarta, 2 February 2001), page 26.

Joeniarto. (1968). Negara Hukum, Jajasan Badan penerbit Gadjah Mada, Jogjakarta, 1968.

Kompas. (2001). "Pesan Moral dari Islah Try Sutrisno dan Korban Kasus Tanjung Priok" (The Moral Message of the Islah between Try Sutrisno and Victims of the Tanjung Priok Case), Kompas, 9 March 2001

Kontras. (2006) Report on Human Rights Court in Indonesia by working groups on Human Rights Court monitoring Program, released at 24 of August 2006.

Kritz, N. (ed). (1995). Transitional Justice, Washington DC: United States Institute of Peace Studies. 
McAdams, A. (ed). (1997). Transitional Justice and the Rule of Law in New Democracies, Notre Dame: University of Notre Dame Press.

Macdonald, R.A. (1998) 'Metaphors of multiplicity: civil society, regimes and legal pluralism'. Arizona Journal of International and Comparative Law 15.

Mahkamah Agung. (2006). Pedoman Unsur-unsur Tindak Pidana Pelanggaran HAM yang Berat dan Pertanggungjawaban Komando, Mahkamah Agung RI, 2006, Hal. 24.

Masyarakat Pemantau Peradilan Indonesia. (2003). The Annotation of the Judicial Decission regarding The Human Rights Court Panel Judges Decission on East Timor Case. Depok: MaPPI FHUI.

McAdams, A (ed). (1997). Transitional Justice and the Rule of Law in New Democracies, Notre Dame: University of Notre Dame Press.

Mudzakkir. (2001). "Posisi Hukum Korban Kejahatan dalam Sistem Peradilan Pidana," (The Legal Position of Victims of Crime in the Criminal Justice System) (Doctoral dissertation. Jakarta: Universitas Indonesia.

Muhammad Yamin. (1958). Proklamasi dan Konstitusi Republik Indonesia (Indonesian Proclamation and Constitution), Ed. V, (Jakarta : Djambatan.

Mumby, D. K. (1993). Narrative and Social Control: Critical Perspective, Sage Publication.

Nordholt, H.S. (2002). A Genealogy of Violence, in Roots of Violence in Indonesia, Leiden: KITLV Press.

Riessman, C. K. (1993). Narrative Analysis : Qualitative Research Methods. California,United Kingdom,India, SAGE, 1993.

Thalib, Sajuti. (1987). Hukum Kewarisan Islam di Indonesia (Law of Inheritance in Indonesia). Jakarta: Bina Aksara.

Rahardjo. Satjipto. (2009). Hukum Progresif: Sebuah Sintesa Hukum Indonesia. Yogyakarta: Genta Publishing.

Security Council of The United Nations. (2005). Summary of the report to the Secretary-General of the Commission of Experts to Review the Prosecution of Serious Violations of Human Rights in Timor-Leste (then East Timor) in 1999 (S/2005/458). Report published by $15^{\text {th }}$ of July 2005.

Soeprapto, Enny. (2010) "Penyelesaian Persoalan HAM di Papua dalam Perspektif Hukum", Paper presented in Discussion on "Persoalan Konflik Papua: Pemetaan Peran dan Kepentingan Aktor" in Indonesian Institute of Sciences, Jakarta, $1^{\text {st }}$ of July 2004. The article was taken from National Human Rights Commission website http://www.komnasham.go.id/portal/id/content/kumpulanmakalah-enny-soeprapto. Accessed by 28th of September 2010.

Squire. (2008). Narrative Analysis. Doing Narrative Research. S. Andrews, Tombokou. Los Angeles, London, New Delhi, Singapore, SAGE.

Strang, Robert R. (2008). "More Adversarial, but not Completely Adversarial": Reformasi of the Indonesian Criminal Procedure Code. Fordham International Law Journal. Volume 32, Issue 1, article 13: Berkley Electronic Press.

Mertokusumo, Sudikno. (1996). Mengenal Hukum (Suatu Pengantar), (Know the Law (An Introduction) $1^{\text {st }}$ edition. Yogyakarta: Liberty.

Sulistiyanto, Priyambudi. (2007). Politics of Justice and Reconciliation in Post Suharto Indonesia, Journal of Contemporary Asia, 37:1.n 73-94.

Teitel, Ruti G. (2000). Transitional Justice. New York: Oxford University Press.

The Indonesian House of Representative Assembly. (2002). The Compilation of TAP MPR 2000 at http://hukum.unsrat.ac.id/etc/putusan mpr 2000.pdf. Last accessed at 18 October 2011 
The Indonesian National Commission on Human Rights. (2000). Annual Report 1999. Jakarta : The Indonesian National Commission on Human Rights.

. (2000). Annual Report 1999. Jakarta : The Indonesian National Commission on Human Rights.

UC Berkley War Crimes Studies Center and Institute for Policy Research and Advocacy (ELSAM). (2008). Monitoring Reports for Ad Hoc Human Rights Court for East Timor in Jakarta, Final Report, 2008. http://warcrimescenter.berkley.edu. Last accessed 27 of November 2011.

United Nations. (1998). Basic Facts About the United Nations. New York: Department of Public Information United Nations. 